\title{
Audio-Visual Services in Colleges and Universities in the United States
}

\author{
Report of a Survey by the ACRL Committee on \\ Audio-Visual Work
}

\author{
Mr. Bennett is librarian, University of Ari- \\ $\approx 0.2 \Omega$.
}

$\mathrm{T}$

HIS is a report of a survey undertaken in March 1952 by the ACRL Committee on Audio-Visual Work. The purpose of the survey was to ascertain the extent to which services with educational films, filmstrips, recordings and other audio-visual materials have been developed in U.S. colleges and universities and, more specifically, the patterns of service which have been evolved in meeting needs for these materials.

It was recognized that sampling techniques would not be wholly appropriate in this survey. Since virtually nothing was known of existing patterns of audio-visual service in academic institutions, there could be no assurance that any randomly selected sample would accurately represent U.S. colleges and universities in terms of audio-visual development. Accordingly, it was decided to conduct a census-type survey.

A carefully-designed questionnaire was sent to the librarians of 1726 colleges and universities. The list of institutions queried comprised the entire college and university mailing list of the ALA Publications Office, with institutions located outside the continental limits of the U.S. deleted. In order to secure comparable data from non-library agencies, there was included with each questionnaire a data sheet to be filled out by the director of any separate audio-visual agency in the institution.

Of the 1726 questionnaires mailed, 4 I were returned because an institution was no longer in existence or because a revised curricular program no longer entitled an institution to status as a college or university. Of the 1685 remaining questionnaires mailed, 575 usable responses $(34 \%)$ were received. It is recognized that because of this relatively small return, the findings presented below may not accurately reflect conditions generally. It might logically be supposed that there would be a greater tendency for institutions having AV services to respond than for those having no such services, and that this would result in skewed analyses. That supposition is at least partially disproved by the fact that $65 \%$ of all responses were from institutions in which there was either no AV service or only a very small one. Although it is believed that the "sample" secured may be fairly representative, it should be understood that all analytical findings presented in this report apply only to the group of institutions from which responses were received.

\section{Patterns of Service}

The survey revealed that $84 \%$ of the reporting institutions had an AV service of some kind. Eighty-nine institutions ( $15 \%$ ) reported a centralized $\mathrm{AV}$ service in the library, and 93 ( $16 \%$ ) reported a centralized service in a separate non-library agency. Decentralized services were reported in $302(53 \%)$ of the institutions. In $22(5 \%)$ of the reporting institutions, the library operated the largest AV service on the campus, while in 236 $(4 \mathrm{I} \%)$ an instructional department (most often the department of education) maintained a service larger than that maintained by the library. Another 44 (7\%) reported a small AV service offered by an instructional department as the only one on the campus.

The data relating to patterns of service in 575 institutions have been analyzed according to three main variables; ( I ) region; (2) type 
TABLE I

Pattern of Audio-Visual Service, By Type of Curricular Program in Institution

\begin{tabular}{|c|c|c|c|c|c|c|}
\hline \multirow[b]{2}{*}{ Pattern of Service } & \multicolumn{5}{|c|}{ Type of Program } & \multirow[b]{2}{*}{$\begin{array}{l}\text { Tota } \\
(\%)\end{array}$} \\
\hline & $\begin{array}{c}\text { Junior } \\
\text { College } \\
(\%)\end{array}$ & $\begin{array}{c}\text { Under- } \\
\text { grad. } \\
(\%)\end{array}$ & $\begin{array}{l}\text { Grad- } \\
\text { uate } \\
(\%)\end{array}$ & $\begin{array}{c}\text { Teacher- } \\
\text { Tng. } \\
(\%)\end{array}$ & $\begin{array}{c}\text { Single- } \\
\text { Subject } \\
(\%)\end{array}$ & \\
\hline $\begin{array}{l}\text { Centralized AV Service in the Li- } \\
\text { brary }\end{array}$ & 23 & 17 & 8 & I 8 & 22 & I5 \\
\hline rate Agency & I I & 6 & 28 & 22 & 5 & 16 \\
\hline has more than other(s) & 2 & 3 & 5 & 7 & 6 & 4 \\
\hline $\begin{array}{l}\text { Decentralized AV Service; Library } \\
\text { has less than other(s) }\end{array}$ & 36 & 48 & $4^{I}$ & 32 & 28 & $4 I$ \\
\hline $\begin{array}{l}\text { Decentralized AV Service; Library } \\
\text { has no service }\end{array}$ & 8 & 7 & 7 & 8 & II & 8 \\
\hline No AV Service on Campus & 20 & I9 & II & I3 & 28 & 16 \\
\hline $\begin{array}{l}\text { Total No. of Institutions } \\
(\mathrm{N}=100 \%)\end{array}$ & 97 & 202 & 190 & 68 & 18 & 575 \\
\hline
\end{tabular}

of curricular program; and (3) size of enrollment.

With one exception, regional differences are not statistically significant. Although the number of cases is small, it would appear that institutions in the Southwest have tended to centralize the administration of their AV services more than those in other regions. Forty-four percent of the reporting colleges and universities in that region have either a central AV service in the library $(18 \%)$ or in a separate non-library agency $(26 \%)$, in contrast to $34 \%$ in the Midwest, $33 \%$ in the Southeast, $31 \%$ in the Northwest, $28 \%$ in the Far West, and $26 \%$ in the Northeast.

Differences of greater significance are re- vealed when the data are analyzed according to the type of curricular program in the reporting institution. Table I shows that among institutions reporting centralized AV services, the junior colleges, undergraduate colleges and single-subject institutions (schools of law, medicine or theology principally) have tended to develop that service in the library, whereas teacher-training and graduate institutions have tended to develop theirs in separate agencies. Single-subject institutions have tended more than others to have no AV service at all. The principle of centralization is shown to have been embraced more generally in teacher-training institutions $(40 \%)$ than in others. Undergraduate colleges are shown to

TABLE II

Pattern of Audio-Visual Service, By Size of Enrollment

\begin{tabular}{|c|c|c|c|c|}
\hline \multirow[b]{2}{*}{ Pattern of Service } & \multicolumn{3}{|c|}{ Size of Enrollment } & \multirow[b]{2}{*}{$\begin{array}{l}\text { Total } \\
(\%)\end{array}$} \\
\hline & $\begin{array}{c}\text { Iooo } \\
\text { or less } \\
(\%)\end{array}$ & $\begin{array}{l}1001- \\
5000 \\
(\%)\end{array}$ & $\begin{array}{l}\text { Over } \\
5000 \\
(\%)\end{array}$ & \\
\hline $\begin{array}{l}\text { Centralized AV Service in the Library } \\
\text { Centralized AV Service in a Separate Agency } \\
\text { Decentralized AV Service; Library has more } \\
\text { than other(s) } \\
\text { Decentralized AV Service; Library has less than } \\
\text { other(s) } \\
\text { Decentralized AV Service; Library has no service } \\
\text { No AV Service on Campus }\end{array}$ & $\begin{array}{r}19 \\
6 \\
4 \\
4 \\
43 \\
8 \\
20\end{array}$ & $\begin{array}{r}11 \\
32 \\
3 \\
37 \\
8 \\
9\end{array}$ & $\begin{array}{r}4 \\
44 \\
4 \\
4 \\
40 \\
2 \\
6\end{array}$ & $\begin{array}{r}15 \\
16 \\
4 \\
4 \\
41 \\
8 \\
16\end{array}$ \\
\hline Total No. Institutions $(\mathrm{N}=100 \%)$ & 366 & I 59 & 50 & 575 \\
\hline
\end{tabular}


have tended more than others to decentralize their AV services with relatively small library participation.

The most sharply distinguishing variable is the size of the institution in terms of enrollment. The results of an analysis along this variable are shown in Table II. The larger the institution, the more likely it is to have developed a centralized AV service. Fortyeight percent of the reporting institutions having an enrollment of over 5000 had centralized services, while only $25 \%$ of those having an enrollment of 1000 or less had centralized services. In the smaller colleges and universities, the centralized service had generally been developed in the library, but in those having an enrollment of more than Iooo, separate AV services had more often been established. Thirty-two percent of the institutions having an enrollment of 1001 to 5000 , and $44 \%$ of those having an enrollment of over 5000 reported central non-library agencies, whereas only $6 \%$ whose en rollment is 1000 or less had established separate centers.

By cross-tabulating the data along both variables, type of curricular program and size of enrollment, it was found that the latter is the more important one. For example, in the group of graduate institutions that reported, only $8 \%$ of the total had centralized their AV services in the library, but $18 \%$ of those graduate schools having an enrollment of 1000 or less had developed a library-centered service.

In all categories except the single-subject institution, analysis reveals that those having enrollments of over 1000 tended more than those having smaller enrollments to have a centralized service, and that it had been developed in a separate agency more often than in the library. It is of some significance to note also that among graduate and teachertraining institutions a disproportionate percentage of the smaller ones maintained no AV service at all on their campuses.

\section{Opinions of Librarians}

The questionnaire included the following opinion question: "Do you believe the library should administer and service all materials of communication for a college or university, including audio-visual materials?" Librarians were asked to respond with a simple affirmative or negative answer, and were given an opportunity to support their opinions with reasons. Fifty-eight percent of those who responded were of the opinion that the library should administer audio-visual services, $32 \%$ responded negatively, and $10 \%$ failed to state an unqualified opinion.

TABLE III

Librarians' Opinions, By Size of Enrollment

\begin{tabular}{|c|c|c|c|c|}
\hline Opinion & $\begin{array}{l}\text { Small } \\
\text { I000 or } \\
\text { Less } \\
(\%)\end{array}$ & $\begin{array}{c}\text { Medium } \\
\text { I00I- } \\
5000 \\
(\%)\end{array}$ & $\begin{array}{l}\text { Large } \\
\text { Over } \\
5000 \\
(\%)\end{array}$ & $\begin{array}{l}\text { Total } \\
(\%)\end{array}$ \\
\hline $\begin{array}{l}\text { Yes } \\
\text { No } \\
\text { No Answer }\end{array}$ & $\begin{array}{l}62 \\
27 \\
\text { I I }\end{array}$ & $\begin{array}{r}54 \\
38 \\
8\end{array}$ & $\begin{array}{l}44 \\
44 \\
\text { I } 2\end{array}$ & $\begin{array}{l}58 \\
32 \\
10\end{array}$ \\
\hline $\begin{array}{l}\text { Total No. of } \\
\text { Librarians } \\
(\mathrm{N}=100 \%)\end{array}$ & 366 & I 59 & 50 & 575 \\
\hline
\end{tabular}

Opinions of librarians were found to vary according to the size of their institutions. (See Table III.) Sixty-two percent of those in the smaller institutions believed that the library should be a complete communications center and include audio-visual materials in their service patterns, while opinion among librarians in institutions having enrollment of over 5000 was split evenly.

Analysis by regional breakdowns and by type of curricular program revealed no significant deviations from over-all patterns of opinion.

The hypothesis that librarians' op:nions were influenced principally by their own experience in handling audio-visual materials was tested by making an analysis according to the pattern of $A V$ service that had been developed in individual institutions. The percentage figures in Table IV reveal that in those institutions in which the library had participated in AV service, the tide of librarians' opinions ran strongly in favor of the library's administering such services. Eighty-five percent of the librarians administering a central AV service, and $65 \%$ of those whose library AV service was the largest on the campus, responded affirmatively. Even in those institutions in which separate agencies had been developed to meet needs for audio-visual materials, nearly half of the librarians $(44 \%$ in colleges and universities having a central nonlibrary agency, and $48 \%$ in those having decentralized services outside the library) 
TABLE IV

Librarians' Opinions, By Degree of Library Participation in Audio-Visual Service

\begin{tabular}{|c|c|c|c|c|c|c|}
\hline \multirow[b]{2}{*}{ Opinion } & \multicolumn{3}{|c|}{ Library Participation } & \multicolumn{2}{|c|}{ Library Non-Participation } & \multirow[b]{2}{*}{$\begin{array}{l}\text { Tota } \\
(\%)\end{array}$} \\
\hline & $\begin{array}{c}\text { Library-cen- } \\
\text { tered AV } \\
\text { Service } \\
(\%)\end{array}$ & $\begin{array}{c}\text { Library has } \\
\text { Major AV } \\
\text { Service } \\
(\%)\end{array}$ & $\begin{array}{c}\text { Library has } \\
\text { Minor AV } \\
\text { Service } \\
(\%)\end{array}$ & $\begin{array}{c}\text { Central AV } \\
\text { Service } \\
\text { in Sep. } \\
\text { Agencies } \\
(\%)\end{array}$ & $\begin{array}{c}\text { Decentral- } \\
\text { ized AV } \\
\text { Services } \\
\text { in Sep. } \\
\text { Agencies } \\
(\%)\end{array}$ & \\
\hline $\begin{array}{l}\text { Yes } \\
\text { No } \\
\text { No Answer }\end{array}$ & $\begin{array}{r}85 \\
12 \\
3\end{array}$ & $\begin{array}{l}65 \\
23 \\
13\end{array}$ & $\begin{array}{l}59 \\
3 \mathrm{I} \\
\text { I0 }\end{array}$ & $\begin{array}{l}44 \\
43 \\
\mathrm{I} 3\end{array}$ & $\begin{array}{l}48 \\
38 \\
14\end{array}$ & $\begin{array}{l}58 \\
32 \\
10\end{array}$ \\
\hline $\begin{array}{l}\text { Total No. of Librar- } \\
\text { ians }(\mathrm{N}=100 \%)\end{array}$ & 89 & 22 & 236 & 93 & I34 & 575 \\
\hline
\end{tabular}

favored central administration of such services in the library.

Sixty-one percent of the librarians who responded to the opinion question submitted one or more reasons in support of their opinions. It is of interest to note that $7 \mathrm{I} \%$ of those who held an affirmative opinion gave reasons, whereas only $41 \%$ of those who held a negative opinion supported their position with reasons.* This would appear to indicate that librarians favoring central library administration of AV services were better prepared (or at any rate more willing) to cite reasons supporting their opinions than were those who believed that the library should not administer such services.

\section{Kinds of Materials Serviced}

In shaping the questionnaire for this survey, the Committee defined "audio-visual materials" by listing six categories only: (I) films; (2) filmstrips; (3) slides; (4) recordings (discs); (5) maps; and (6) pictures, including photographs. It was recognized that other materials could be included (e.g., tape and wire recordings), but it was thought advisable to limit the investigation to the six categories cited.

All respondents, including directors of separate $A V$ agencies, were asked to check which materials they serviced, and the size of the collection in each case. Table $\mathrm{V}$ shows the proportions of library and non-library agencies in the reporting institutions which gave service in the various categories of materials.

* Reasons given by respondents have been analyzed by Carl W. Hintz in a separate paper, as yet un published.
In institutions having centralized AV services, $99 \%$ of the separate agencies and $87 \%$ of the library centers give service with films. Ninety-three percent of the separate agencies and $90 \%$ of the library centers give service with filmstrips. Eighty-nine percent of the library centers include recordings in their service patterns, while only $70 \%$ of the separate agencies give service with recordings. A majority of each type of center handle slides,

\section{TABLE V}

Proportion of Libraries and Non-Library AudioVisual Agencies Giving Service with Specified Types of Materials

\begin{tabular}{|c|c|c|c|c|c|}
\hline \multirow{2}{*}{$\begin{array}{c}\text { Materials } \\
\text { Serviced }\end{array}$} & \multirow{2}{*}{$\begin{array}{l}\text { Lib. } \\
\text { Cent. } \\
(\%)\end{array}$} & \multirow{2}{*}{$\begin{array}{c}\text { Sep. } \\
\text { Cent. } \\
(\%)\end{array}$} & \multicolumn{2}{|c|}{ Dęcentral. } & \multirow{2}{*}{$\begin{array}{c}\text { Other } \\
\text { Minor } \\
(\%)\end{array}$} \\
\hline & & & $\begin{array}{l}\mathrm{Lib} \\
(\%)\end{array}$ & $\begin{array}{l}\text { Other } \\
(\%)\end{array}$ & \\
\hline Films & 87 & 99 & 26 & 94 & 94 \\
\hline Filmstrips & 90 & 93 & 37 & 84 & $8 \mathrm{I}$ \\
\hline Slides & 65 & 72 & 31 & 64 & $44^{\circ}$ \\
\hline Recordings & 89 & 70 & 63 & 47 & 50 \\
\hline Maps & 62 & 26 & 72 & 20 & 19 \\
\hline Pictures & 73 & 32 & 64 & $2 \mathrm{I}$ & 6 \\
\hline
\end{tabular}

No. of Insti-

tutions

$(\mathrm{N}=100 \%) \quad 89 \quad 90 \quad 256 \quad 86 \quad 16$

but whereas approximately two-thirds of the library centers render service with maps and pictures, only a little over one-fourth of the separate agencies service these materials.

It would appear that separate $\mathrm{AV}$ agencies have tended to concentrate on service with films and filmstrips, and largely to ignore maps 
TABLE VI

Overlapping Services with Specified Audio-Visual Materials in Institutions Having Decentralized Audio-Visual Services

\begin{tabular}{|c|c|c|c|c|c|c|}
\hline \multirow[b]{2}{*}{ Overlap Status } & \multicolumn{6}{|c|}{ Audio-Visual Materials } \\
\hline & $\underset{(\%)}{\text { Films }}$ & $\begin{array}{l}\text { Film- } \\
\text { strips } \\
(\%)\end{array}$ & $\begin{array}{l}\text { Slides } \\
(\%)\end{array}$ & $\begin{array}{l}\text { Record- } \\
\text { ings } \\
(\%)\end{array}$ & $\begin{array}{c}\text { Maps } \\
(\%)\end{array}$ & $\begin{array}{l}\text { Pictures } \\
(\%)\end{array}$ \\
\hline $\begin{array}{l}\text { Overlapping Service } \\
\text { No Overlapping Service }\end{array}$ & $\begin{array}{r}9 \\
91\end{array}$ & $\begin{array}{l}13 \\
87\end{array}$ & $\begin{array}{l}15 \\
85\end{array}$ & $\begin{array}{l}12 \\
88\end{array}$ & $\begin{array}{r}6 \\
94\end{array}$ & $\begin{array}{r}6 \\
94\end{array}$ \\
\hline $\begin{array}{l}\text { Total No. of Institutions* } \\
(\mathrm{N}=100 \%)\end{array}$ & 148 & I 66 & I 35 & 210 & $20 \mathrm{I}$ & 182 \\
\hline
\end{tabular}

* Base figures represent the proportion of 258 institutions with decentralized service which give service in each category of materials.

and pictures. On the other hand, the library center has tended to include all the recognized AV materials, thus probably rendering more complete centralized services than are usually available on campuses where AV services have been the responsibility of separate non-library agencies.

In the institutions where AV services have been decentralized, with libraries participating, Table $\mathrm{V}$ reveals that the libraries have tended to concentrate on service with recordings, maps and pictures, while the non-library agencies have concentrated on services involving films, filmstrips and slides. However, there has been some overlap in the services of the libraries and separate agencies in these institutions, as shown in Table VI. Although the degree of overlap is small, a legitimate question can be raised as to the appropriateness of any overlap at all, especially in the light of budgetary implications of such duplication of service. It is demonstrated in Table VII that the overlapping has occurred principally in the smaller institutions, rather than in the larger institutions whose budgets would probably be less seriously affected by it.

\section{Size of Collections}

Librarians and directors of non-library AV agencies were asked to indicate the size of their collections of audio-visual materials. Most respondents who administered AV services submitted relevant data, but for purposes of analysis, in all cases where size-of-collection data were not given, it was assumed that the collection was small and could be appropriately assigned to the smallest sizecategory.

The size of institutional enrollment proved, as was expected, to be the principal factor determining the size of audio-visual collections. As shown in Tables VIII-X, an over-

\section{TABLE VII}

Overlapping Audio-Visual Services in Institutions Having Decentralized Arrangement, By Size of Institutional Enrollment

\begin{tabular}{|c|c|c|c|c|c|c|}
\hline \multirow[b]{2}{*}{ Size of Enrollment } & \multicolumn{6}{|c|}{ Audio-Visual Materials } \\
\hline & $\underset{(\%)}{\text { Films }}$ & $\begin{array}{l}\text { Film- } \\
\text { strips } \\
(\%)\end{array}$ & $\begin{array}{c}\text { Slides } \\
(\%)\end{array}$ & $\begin{array}{l}\text { Record - } \\
\text { ings } \\
(\%)\end{array}$ & $\begin{array}{c}\text { Maps } \\
(\%)\end{array}$ & $\begin{array}{c}\text { Pictures } \\
(\%)\end{array}$ \\
\hline Small & 36 & 53 & 50 & 44 & $6 I$ & 55 \\
\hline Medium & $2 I$ & I 4 & 20 & 24 & 23 & I 8 \\
\hline Large & 43 & 33 & 30 & 32 & 16 & 27 \\
\hline $\begin{array}{l}\text { No. of Institutions with Over- } \\
\text { lapping Service }(\mathrm{N}=\mathrm{I} 00 \%)\end{array}$ & 14 & $2 \mathrm{I}$ & 20 & 25 & 13 & I I \\
\hline
\end{tabular}


TABLE VIII

Size of Film Collection, By Size of Enrollment and Pattern of Audio-Visual Service

\begin{tabular}{|c|c|c|c|c|c|c|c|c|c|c|c|c|c|c|c|}
\hline \multirow{3}{*}{$\begin{array}{c}\text { Size of } \\
\text { Film } \\
\text { Collection }\end{array}$} & \multicolumn{5}{|c|}{ Small: 1000 or Less } & \multicolumn{5}{|c|}{ Medium: $1001-5000$} & \multicolumn{5}{|c|}{ Large: Over 5000} \\
\hline & \multirow{2}{*}{ 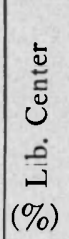 } & \multirow{2}{*}{ 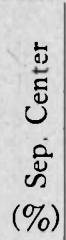 } & \multicolumn{2}{|c|}{$\begin{array}{l}\text { Decentral- } \\
\text { ized Serv. }\end{array}$} & \multirow{2}{*}{ 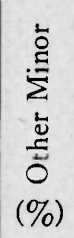 } & \multirow{2}{*}{ 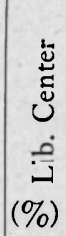 } & \multirow{2}{*}{$\begin{array}{c}\stackrel{ \pm}{u} \\
\text { Ũ } \\
u \\
\dot{0} \\
\tilde{N} \\
(\%)\end{array}$} & \multicolumn{2}{|c|}{$\begin{array}{l}\text { Decentral- } \\
\text { ized Serv. }\end{array}$} & \multirow{2}{*}{ 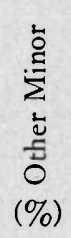 } & \multirow{2}{*}{ 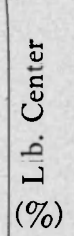 } & \multirow{2}{*}{ 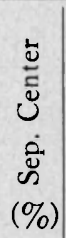 } & \multicolumn{2}{|c|}{$\begin{array}{l}\text { Decentral- } \\
\text { ized Serv. }\end{array}$} & \multirow{2}{*}{ 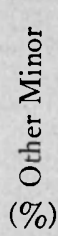 } \\
\hline & & & 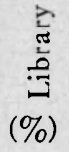 & 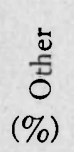 & & & & 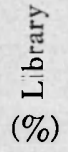 & $\begin{array}{c}\stackrel{5}{\leftrightarrows} \\
-5 \\
0 \\
(\%)\end{array}$ & & & & 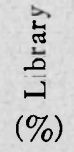 & $\begin{array}{c}\stackrel{5}{ \pm} \\
\stackrel{5}{5} \\
(\%)\end{array}$ & \\
\hline IO & 88 & 67 & 95 & 88 & 100 & 63 & 40 & 94 & $5^{\varepsilon}$ & 75 & 0 & $I_{4}$ & 100 & I & 0 \\
\hline IOI & I 2 & 24 & 5 & 8 & 0 & 31 & 40 & & It & 0 & 50 & $I_{4}$ & 0 & 29 & 0 \\
\hline $501-1000$ & 0 & 0 & 0 & 4 & 0 & 6 & II & 0 & I I & 25 & 50 & 9 & o & 7 & 0 \\
\hline & 0 & 9 & $\circ$ & 0 & 0 & 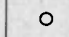 & 0 & $\circ$ & 10 & 0 & 0 & 36 & 0 & 42 & 0 \\
\hline Over 3000 & 0 & 0 & $\circ$ & $\circ$ & $\circ$ & 0 & o & $\circ$ & 5 & $\circ$ & $\circ$ & 27 & $\circ$ & 7 & $\circ$ \\
\hline $\begin{array}{l}\text { ncies } \\
=100 \%)\end{array}$ & 59 & $2 \mathrm{I}$ & 43 & 49 & I I & I6 & 47 & I 7 & 19 & 4 & 2 & 22 & 9 & I 4 & 0 \\
\hline
\end{tabular}

whelming majority of the collections in small institutions fall into the two smallest sizecategories, and that in the larger institut:ons the collections, although still concentrated in the smaller size-categories, tend to be larger. It is of some significance to note that, in the case of films and filmstrips, the collections in separate agencies tend to be larger than those in library-centered AV services, but that, in the case of recordings, the reverse is true.

A scrutiny of these tables clearly reveals that the development of audio-visual collections is still in its early stages. Relatively few libraries or separate $A V$ agencies. have acquired large collections of films, filmstrips or recordings. The same is true of the other three categories of $\mathrm{AV}$ materials, although comparable tabulations of data are not presented here. The one exception indicated by an examination of the data is maps, of which several libraries reported sizable collections. Most of these are probably libraries in which the U. S. Army Map Service has deposited maps since World War II. Virtually no separate $A V$ agencies have collected maps in great numbers.

TABLE IX

Size of Collections of Recordings, By Size of Enrollment and Pattern of Audio-Visual Service

\begin{tabular}{|c|c|c|c|c|c|c|c|c|c|c|c|c|c|c|c|}
\hline \multirow{3}{*}{$\begin{array}{l}\text { Size of } \\
\text { Collections of } \\
\text { Recordings }\end{array}$} & \multicolumn{5}{|c|}{ Small: 1000 or Less } & \multicolumn{5}{|c|}{ Medium: $100 \mathrm{I}-5000$} & \multicolumn{5}{|c|}{ Large: Over 5000} \\
\hline & \multirow{2}{*}{ 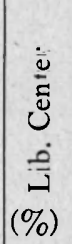 } & \multirow{2}{*}{ 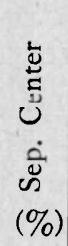 } & \multicolumn{2}{|c|}{$\begin{array}{l}\text { Decentral- } \\
\text { ized Serv. }\end{array}$} & \multirow{2}{*}{ 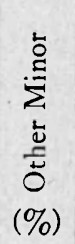 } & \multirow{2}{*}{ 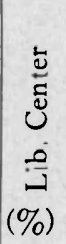 } & \multirow{2}{*}{ 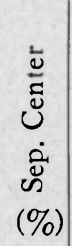 } & \multicolumn{2}{|c|}{$\begin{array}{l}\text { Decentral- } \\
\text { ized Serv. }\end{array}$} & \multirow{2}{*}{ 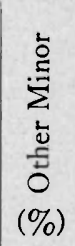 } & \multirow{2}{*}{ 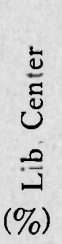 } & \multirow{2}{*}{$\begin{array}{c}\frac{\tilde{u}}{\tilde{J}} \\
\tilde{u} \\
\dot{0} \\
\tilde{u} \\
(\%)\end{array}$} & \multicolumn{2}{|c|}{$\begin{array}{l}\text { Decentral- } \\
\text { ized Serv. }\end{array}$} & \multirow{2}{*}{ 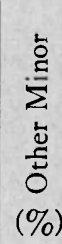 } \\
\hline & & & (\%) & $\begin{array}{c}\stackrel{0}{\underline{\Xi}} \\
0 \\
(\%)\end{array}$ & & & & (\%) & 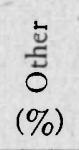 & & & & 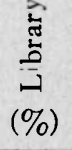 & $\begin{array}{c}\stackrel{0}{ \pm} \\
\stackrel{\Xi}{0} \\
(\%)\end{array}$ & \\
\hline 200 & 58 & 86 & 55 & 100 & 83 & 35 & 69 & $4 !$ & 67 & 100 & 0 & 59 & 2 & 50 & 100 \\
\hline & 30 & $I_{4}$ & 23 & $\circ$ & 0 & 24 & 28 & 27 & 33 & $\circ$ & 50 & 30 & I3 & $3 c$ & 0 \\
\hline $1, \infty$ I & I 2 & 0 & 20 & 0 & 17 & 29 & 3 & 20 & 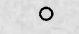 & o & 50 & 6 & $3^{I}$ & IO & 0 \\
\hline $5, \infty 0 \mathrm{I}-15, \infty 00$ & 0 & $\circ$ & 2 & $\circ$ & $\circ$ & 12 & $\circ$ & I 2 & 0 & $\circ$ & o & 5 & $3^{1}$ & 10 & 0 \\
\hline Over I $5, \infty 00$ & 0 & 0 & 0 & $\circ$ & $\circ$ & $\circ$ & 0 & 0 & 0 & o & 0 & o & 0 & 0 & 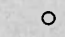 \\
\hline $\begin{array}{l}\text { Total No. of } \\
\text { Agencies } \\
(\mathrm{N}=100 \%)\end{array}$ & 60 & $I_{4}$ & II 2 & $2 \mathrm{I}$ & 6 & 17 & 32 & 44 & 9 & 2 & 2 & 17 & 16 & IO & I \\
\hline
\end{tabular}


TABLE X

Size of Filmstrip Collections, By Size of Enrollment and Pattern of Audio-Visual Service

\begin{tabular}{|c|c|c|c|c|c|c|c|c|c|c|c|c|c|c|c|}
\hline \multirow{3}{*}{$\begin{array}{l}\text { Size of } \\
\text { Filmstrip } \\
\text { Collections }\end{array}$} & \multicolumn{5}{|c|}{ Small: I000 or Less } & \multicolumn{5}{|c|}{ Medium : $1001-5000$} & \multicolumn{5}{|c|}{ Large: Over 5000} \\
\hline & \multirow{2}{*}{ 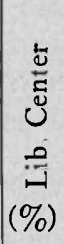 } & \multirow{2}{*}{ 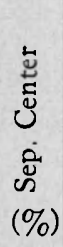 } & \multicolumn{2}{|c|}{$\begin{array}{l}\text { Decentral- } \\
\text { ized Serv. }\end{array}$} & \multirow{2}{*}{ 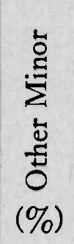 } & \multirow{2}{*}{ 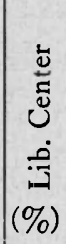 } & \multirow{2}{*}{ 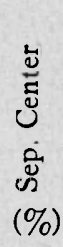 } & \multicolumn{2}{|c|}{$\begin{array}{l}\text { Decentral- } \\
\text { ized Serv. }\end{array}$} & \multirow{2}{*}{ 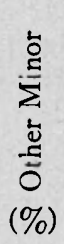 } & \multirow{2}{*}{ 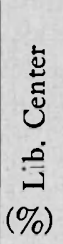 } & \multirow{2}{*}{ 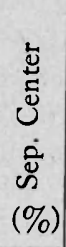 } & \multicolumn{2}{|c|}{$\begin{array}{l}\text { Decentral- } \\
\text { ized Serv. }\end{array}$} & \multirow{2}{*}{ 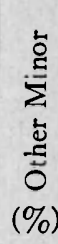 } \\
\hline & & & 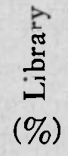 & $\begin{array}{c}\stackrel{5}{ \pm} \\
\stackrel{5}{0} \\
(\%)\end{array}$ & & & & $\underset{(\%)}{\stackrel{5}{5}}$ & 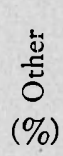 & & & & 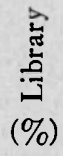 & 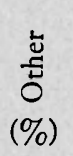 & \\
\hline 100 or less & 75 & 50 & 85 & 75 & 80 & 65 & 33 & 83 & 53 & 100 & 0 & 20 & 77 & 10 & 100 \\
\hline $100-500$ & 23 & 33 & 13 & 23 & 20 & 29 & 54 & 9 & 33 & 0 & 100 & 45 & 23 & 50 & o \\
\hline $501-1000$ & 2 & I I & 2 & 2 & 0 & 6 & 9 & 4 & I 4 & c & 0 & IO & 0 & 20 & 0 \\
\hline $1001-3000$ & 0 & 6 & 0 & 0 & 0 & 0 & 4 & 0 & 0 & 0 & ० & 25 & 0 & 20 & c \\
\hline Over 3000 & 0 & 0 & 0 & 0 & 0 & 0 & 0 & 4 & 0 & 0 & 0 & 0 & 0 & 0 & 0 \\
\hline $\begin{array}{l}\text { Total No. of } \\
\text { Agencies } \\
(\mathrm{N}=100 \%)\end{array}$ & $6 I$ & I 8 & 62 & 48 & IO & I 7 & 46 & 23 & I 5 & 3 & 2 & 20 & 9 & 10 & I \\
\hline
\end{tabular}

\section{Circulation of Materials}

In the reporting institutions, circulation of audio-visual materials tended to be limited to the local campus. However, many library and non-library $A V$ agencies reported giving service to the local community and, in progressively smaller numbers, to the state or region in which the institution was located. Very few agencies reported their willingness to send audio-visual materials throughout the entire United States. Analysis by size of institution and pattern of service reveals that circulation of $\mathrm{AV}$ materials is somewhat more likely to be restricted to the campus in the smaller institutions, and is likely to be somewhat less

TABLE XI

Audio-Visual Services Available, By Size of Enrollment and Pattern of AV Service

\begin{tabular}{|c|c|c|c|c|c|c|c|c|c|c|c|c|c|c|c|}
\hline \multirow{3}{*}{$\begin{array}{l}\text { Services } \\
\text { Available }\end{array}$} & \multicolumn{5}{|c|}{ Small: I000 or Less } & \multicolumn{5}{|c|}{ Medium: $100 \mathrm{I}-5000$} & \multicolumn{5}{|c|}{ Large: Over 5000} \\
\hline & \multirow{2}{*}{ 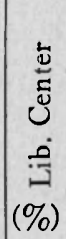 } & \multirow{2}{*}{ 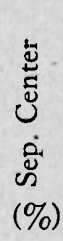 } & \multicolumn{2}{|c|}{$\begin{array}{l}\text { Decentral- } \\
\text { ized Serv. }\end{array}$} & \multirow{2}{*}{ 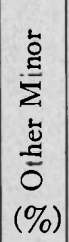 } & \multirow{2}{*}{ 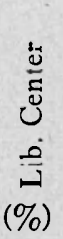 } & \multirow{2}{*}{ 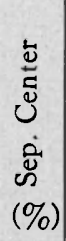 } & \multicolumn{2}{|c|}{$\begin{array}{l}\text { Decentral- } \\
\text { ized Serv. }\end{array}$} & \multirow{2}{*}{ 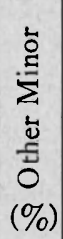 } & \multirow{2}{*}{ 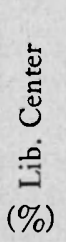 } & \multirow{2}{*}{ 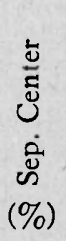 } & \multicolumn{2}{|c|}{$\begin{array}{l}\text { Decentral- } \\
\text { ized Serv. }\end{array}$} & \multirow{2}{*}{ 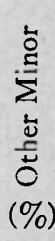 } \\
\hline & & & 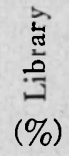 & $\begin{array}{c}\stackrel{\bigsqcup}{ \pm} \\
\stackrel{\Xi}{0} \\
(\%)\end{array}$ & & & & 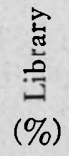 & 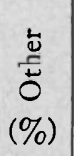 & & & & 芶 & $\begin{array}{c}\stackrel{5}{\Xi} \\
\stackrel{5}{0} \\
(\%)\end{array}$ & \\
\hline Projectors & 83 & 100 & 24 & 94 & 92 & 94 & 98 & 27 & 100 & 75 & 100 & 100 & 32 & 100 & 0 \\
\hline Record Players & 70 & 86 & $4^{2}$ & 74 & $5^{8}$ & 89 & $9 \mathrm{I}$ & $4 \mathrm{I}$ & 63 & 50 & 100 & 59 & 45 & 50 & $\circ$ \\
\hline Projectionists & 59 & $8 \mathrm{I}$ & I I & $8 \mathrm{I}$ & 75 & 83 & $9 \mathrm{I}$ & 8 & 84 & 50 & 100 & 100 & 18 & 86 & 0 \\
\hline Listening Rooms & 48 & 48 & $3 I$ & 43 & 33 & $6 I$ & 70 & 36 & 26 & 50 & 100 & 50 & 32 & 36 & 0 \\
\hline Viewing Rooms & 57 & 86 & 15 & 87 & 58 & 78 & 94 & 16 & 26 & 75 & 100 & 95 & I 8 & 86 & 0 \\
\hline Recording Serv. & $4 \mathrm{I}$ & $8 \mathrm{I}$ & IO & 57 & 33 & 33 & 74 & 6 & 63 & 50 & 100 & 64 & 23 & 57 & 0 \\
\hline $\begin{array}{l}\text { duction } \\
\text { Instruction in Use }\end{array}$ & & & 6 & 30 & 8 & 17 & 55 & I I & 53 & 50 & $\circ$ & 50 & 27 & 29 & $\circ$ \\
\hline of Equip. & 58 & $8 \mathrm{I}$ & I 8 & 87 & 83 & 78 & 94 & I 3 & 79 & 50 & 50 & $9 \mathrm{I}$ & 27 & 71 & $\circ$ \\
\hline sultation & 55 & 67 & 39 & 56 & 42 & 83 & 9 I & 34 & 68 & 50 & 100 & 86 & 55 & $7 \mathrm{I}$ & $\circ$ \\
\hline Other Services & 6 & 5 & 7 & 4 & 0 & 22 & 9 & 2 & $2 I$ & 0 & 50 & 23 & 9 & $2 \mathrm{I}$ & $\circ$ \\
\hline $\begin{array}{l}\text { Total No. of Agencies } \\
(\mathrm{N}=100 \%)\end{array}$ & 69 & $2 \mathrm{I}$ & I 70 & 54 & 12 & I 8 & 47 & 64 & I9 & 4 & 2 & 22 & 22 & I 4 & 0 \\
\hline
\end{tabular}


restricted in separate agencies than in librarycentered AV services.

\section{Audio-Visual Services Offered}

A checklist of equipment, facilities and services was provided in the questionnaire, in an attempt to secure data about services other than loans of materials given by library and non-library AV agencies. The results of an analysis of these data are shown in Table XI.

The pattern of percentages in this respect parallel closely those of Table V. The libraries which give service with films and filmstrips usually provide service with projectors; projectionist service is given less frequently, and viewing rooms are also less offer services other than circulation of materials. However, the fact that responses from a majority of non-library agencies in this group were not received makes it impossible to draw that conclusion. Whereas 256 of the 258 libraries in institutions having decentralized AV service submitted data, replies from only 87 of the non-library AV agencies in those same institutions were received, and the proportions shown in both Tables $\mathrm{V}$ and $X I$ are based upon the number of agencies which reported.

The picture becomes a little clearer by scrutinizing the raw figures for the columns in Table XI under "Decentralized Service" for each size-category, which are shown below. These figures reveal that in the small-enroll-

\begin{tabular}{|c|c|c|c|c|c|c|}
\hline \multirow{2}{*}{ Services Available } & \multicolumn{2}{|c|}{ Small: 1000 or Less } & \multicolumn{2}{|c|}{ Medium: $1001-5000$} & \multicolumn{2}{|c|}{ Large: Over 5000} \\
\hline & Lib. & Other & Lib. & Other & Lib. & Other \\
\hline Projectors & 40 & $5 \mathrm{I}$ & 17 & 19 & 7 & 14 \\
\hline Record Players & 72 & 40 & 26 & 12 & 10 & 7 \\
\hline Projectionist Service & 18 & 44 & 5 & 16 & 4 & 12 \\
\hline Listening Rooms & 53 & 23 & 23 & 5 & 7 & 5 \\
\hline Viewing Rooms & 25 & 47 & I0 & 15 & 4 & 12 \\
\hline Recording Service & 17 & 31 & 4 & 12 & 5 & 8 \\
\hline Photographic Production & 10 & 16 & 7 & 10 & 6 & 4 \\
\hline Instruction & 30 & 47 & 8 & 15 & 6 & 10 \\
\hline Reference and Consultation & 66 & 30 & 22 & I3 & 12 & 10 \\
\hline Other Services & 12 & 2 & I & 4 & 2 & 3 \\
\hline
\end{tabular}

frequently available. The separate agencies are more likely than libraries are to provide projectors and projectionists, and to have facilities for viewing films.

Although a large proportion of AV agencies have record players available for their patrons, a far smaller proportion have special listening rooms. It is probable that many of these AV agencies have earphone attachments for record players located in public or semi-public areas.

A comparison of Tables $\mathrm{V}$ and XI reveals the quite unexpected finding that although only three-fifths of the separate AV centers give service with recordings or have any collections of them, approximately $82 \%$ of them have record players for the use of students and other patrons. There is no ready explanation for this phenomenon.

In the institutions reporting decentralized AV services, it would appear that, whether large or small, the non-library AV agencies are more likely than library $\mathrm{AV}$ agencies to ment group, 40 of the libraries ( $24 \%$ of $\mathrm{I} 70$ ) reported service with projectors, and $5 \mathrm{I}$ of the non-library agencies ( $94 \%$ of 54 , but only $30 \%$ of I70) reported this service. In the case of service with record players in the same size-category, 72 of the libraries ( $42 \%$ of I 70) reported service, whereas only 40 of the non-library agencies ( $74 \%$ of 54 , but only $24 \%$ of I70) reported giving this service. Examples of the same kind can be cited in the larger size-categories to illustrate the fallacy of basing an analysis on the percentage figures in Table XI alone.

\section{Personnel, Budgets, and Statistics of Use}

An effort was made in the survey to secure data from librarians and directors of separate $A V$ agencies on ( $I$ ) the number of persons engaged in audio-visual work at various levels; (2) the amounts budgeted during the previous year for materials, equipment and personnel; and (3) statistics of use of audio-visual materials over a four-year period. Unfortu- 
nately, only a very small number of respondents submitted full or reliable data; hence, no analysis on these points can be presented here.

\section{SuMmary}

Among the 575 institutions from which data were secured in this survey, it is clear that needs for audio-visual materials have been recognized and steps taken in a large majority $(84 \%)$ of them to meet those needs. It is not known how adequate the services in individual institutions are, since needs undoubtedly vary widely according to patterns of instruction and size of enrollments, but the reported size of collections and extent of services provided indicate that probably in only a very few U.S. colleges and universities have adequate AV services been developed.

Although the theoretical advantages of centralizing $A V$ services appear to be great, this survey reveals that in less than one-third of the reporting institutions have these services been centralized. The larger institutions have embraced the principle of centralization more often than the smaller institutions, and have tended to set up separate AV agencies, whereas among the smaller institutions the central AV services have been developed more often in the library.

Librarians in the 575 institutions generally believed that the library should incorporate audio-visual materials into their service patterns. Those in smaller institutions and those who had administered AV services tended to express this opinion more often than those in larger institutions or those in whose libraries no AV services had been developed.

Centralized non-library AV agencies have tended to develop service with films and filmstrips and to ignore other AV materials such as maps and pictures, whereas library-centered AV services have tended to include all the recognized materials in this area. In those institutions where AV services have been developed on a decentralized basis, the libraries have concentrated on services with recordings, maps and pictures, while the non-library agencies have concentrated on service with films, filmstrips and slides. The amount of overlap between the services of library and non-library agencies has been small, but has occurred principally in the smaller institutions where the budgetary implications of overlapping services are probably more serious than in larger institutions.

The statistical tabulations included in this report reveal that there has not yet been any extensive development of AV services in U.S. colleges and universities, but there is reason to believe that the rate of development will become greatly accelerated within the next few years. Many librarians, in annotating their questionnaires or in writing letters, asserted that AV services were shortly to be inaugurated in their institutions or that existing services were soon to be expanded. They indicated that the development of AV services on their campuses had been hampered by difficulties in allocating space in outmoded buildings and in securing adequate budgetary support, but that solutions for these problems were being found.

It may be that this survey was taken at or near a turning point in the development of $\mathrm{AV}$ services in colleges and universities, and that a survey taken five years hence might reveal many significant changes.

\section{Drexel Scholarships}

Three full tuition scholarships are being offered at the Drexel School of Library Science for the academic year 1955-56. These are available to students matriculating in the full time course leading to the Master's degree. Applicants must be American citizens, who give evidence of high academic records at approved colleges or universities, and who have need for financial aid.

Applicants should apply to the dean of the School of Library Science, Drexel Institute of Technology, 32nd and Chestnut Streets, Philadelphia 4, Pennsylvania before April I, I955. Scholarship information for foreign students will also be obtainable from the dean. 